\title{
Four novel Arthrobacter species isolated from filtration substrate
}

Correspondence

Linxian Ding

dinglinxian@hotmail.com
Linxian Ding, ${ }^{1,2}$ Taketo Hirose ${ }^{1,2}$ and Akira Yokota ${ }^{2}$

\author{
${ }^{1}$ Hirose Laboratory Environmental Microorganism, Honcho, Funabashi-City, Chiba Pref. 4-43-20, \\ Japan \\ ${ }^{2}$ Laboratory of Bioresources, Institute of Molecular and Cellular Biosciences, The University of \\ Tokyo, Yayoi, Bunkyo-ku, Tokyo 113-0032, Japan
}

The genus Arthrobacter was established by Conn \& Dimmick (1947) and includes most of the bacteria that exhibit a rod (in young cultures)-coccus (in older cultures) morphological cycle, although some members of the genus are spheres, occurring in pairs and tetrads, such as Arthrobacter agilis. The members of this genus have been isolated from various environments, such as air, soil, fresh water, oil, brine, airborne infections, tobacco leaves, human skin, mural paintings, sewage and activated sludge (Sguros, 1955; Li et al., 2004; Conn \& Dimmick, 1947; Takeuchi \& Yokota, 1991; Stackebrandt et al., 1983; Westerberg et al., 2000; Koch et al., 1995; Heyrman et al., 2005; Skerman et al., 1980; Margesin et al., 2004, Rzechowska, 1976). It has been reported that some poisonous contaminants and difficult-to-degrade chemical substances (such as PCB, dioxin and oil) can be degraded by species of the genus Arthrobacter (Rzechowska, 1976; Marks et al., 1984; Singer et al., 2000; Duarte et al., 2001; Fukatsu et al., 2005; Jussila et al., 2006). Denitrification

The GenBank/EMBL/DDBJ accession number for the 16S rRNA gene sequences of Arthrobacter niigatensis $\mathrm{LC}^{\top}$, Arthrobacter alkaliphilus $\mathrm{LC}^{\top}$, Arthrobacter echigonensis $\mathrm{LC} 10^{\top}$ and Arthrobacter albidus $\mathrm{LC}^{\mathrm{C}} 3^{\top}$ reported in this paper are AB248526, AB248527, AB248531 and AB248533, respectively. activity has been described for some species of the genus Arthrobacter (Carter et al., 1995). At the present time, there are more than 50 recognized species of the genus Arthrobacter. This study describes four high G $+\mathrm{C}$, Grampositive bacterial strains, $\mathrm{LC}^{\mathrm{T}}, \mathrm{LC}^{\mathrm{T}}, \mathrm{LC} 10^{\mathrm{T}}$ and $\mathrm{LC} 13^{\mathrm{T}}$ which were isolated from a filtration substrate and, from the results of a polyphasic taxonomic approach, are suggested to represent four novel species of the genus Arthrobacter.

The bacterial strains were isolated from a filtration substrate made from volcanic soil using NY medium ( $1.6 \mathrm{~g}$ nutrient broth $\mathrm{l}^{-1}$ and $0.5 \mathrm{~g}$ yeast extract $\mathrm{l}^{-1}$ ) containing $0.05 \mathrm{~g}$ cycloheximide $1^{-1}, 0.1 \mathrm{~g}$ kabicidin $1^{-1}$, $1.5 \%$ agar and adjusted to $\mathrm{pH}$ to 7.0. All isolates were maintained on NY medium. The reference strains used in this study, Arthrobacter methylotrophus IAM $15313^{\mathrm{T}}$, Arthrobacter atrocyaneus IAM $12339^{\mathrm{T}}$ and Arthrobacter chlorophenolicus JCM $12360^{\mathrm{T}}$ were obtained from the IAM Culture Collection (University of Tokyo, Japan) and JCM (Japan Collection of Microorganisms). All strains were cultured at $30{ }^{\circ} \mathrm{C}$. Genomic DNA extraction (Sambrook et al., 1989) and PCR-mediated amplification of the $16 \mathrm{~S}$ rRNA gene and sequencing of the PCR products were carried out as described previously (Ding \& Yokota, 2002, 2004). Sequence alignment was performed using CLUSTAL_X 
v1.83 (Thompson et al., 1994). The evolutionary distance matrix was calculated using Kimura's two-parameter method (Kimura, 1980). A phylogenetic tree was constructed by the neighbour-joining (Saitou \& Nei, 1987) and maximum-likelihood methods (Felsenstein, 1981). The topology of the phylogenetic tree was evaluated by bootstrap analysis with 1000 replications according to the method of Felsenstein (1985). The G+C content of the DNA was determined by HPLC as described by Mesbah et al. (1989). DNA-DNA relatedness experiments were conducted using a modification of the microplate method of Ezaki et al. (1989) and using photobiotin-labelled DNA and microdilution wells as described by Willems et al. (2001). The DNA-DNA hybridization temperature was $55{ }^{\circ} \mathrm{C}$.

Analysis of cell-wall amino acids was performed by suspending $300 \mathrm{mg}$ of dried cells in $10-20 \mathrm{ml}$ of water and then around $1 \mathrm{~g}$ of glass beads $(0.11-0.12 \mathrm{~mm}$ in diameter) was added and the suspension was treated at $180 \mathrm{~W}$ for $30 \mathrm{~min}$ using an ultrasonicator $(201 \mathrm{M}$ ultrasonic oscillator; Kubota). The crude cell wall preparation was washed with water, centrifuged in $4 \%$ SDS solution to eliminate proteins and the purified cell walls were freezedried. The amino acid composition was determined by TLC followed by HPLC. For two dimensional TLC, 2propanol/acetic acid/water $(75: 10: 15, \mathrm{v} / \mathrm{v})$ was used in the first dimension and methanol-pyridine/10 $\mathrm{M}$ hydrochloric acid/water $(64: 8: 2: 14, \mathrm{v} / \mathrm{v})$ was used for the second dimension. The amino acids of the cell-wall peptidoglycan were determined according to the methods of Schleifer \& Kandler (1972) and Harper \& Davis (1979). The cellular fatty acids were extracted according to the protocol of the MIDI system (Microbial ID Inc.). The bacteria were incubated in TSBA medium for $48 \mathrm{~h}$ at $30{ }^{\circ} \mathrm{C}$. The fatty acid methyl esters (FAMEs) were obtained from the cells by saponification, methylation and extraction. Analysis by GC was controlled by MIS software (Microbial ID Inc.) and the peaks were automatically integrated and identified by the Microbial Identification software package (Sasser, 1990). Isoprenoid quinones were extracted with chloroform/ methanol $(2: 1, \mathrm{v} / \mathrm{v})$ and purified by TLC using $\mathrm{n}$ hexane-diethyl ether $(85: 15, \mathrm{v} / \mathrm{v})$ as the solvent and the menaquinone fraction was analysed by HPLC.

The biochemical profile was determined with API ZYM and API CORYNE strips (bioMérieux). The optimum temperature and the $\mathrm{pH}$ for growth were also determined. The range of test temperatures was $5,10,20,30,37,40,45$ and $50{ }^{\circ} \mathrm{C}$ and the $\mathrm{pH}$ range tested was $4,5,6,6.5,7,7.5,8$, $8.5,9,9.5,10,11$ and 12 . The results of $\mathrm{NaCl}$ tolerance tests were obtained with 3,5 and $7 \%(\mathrm{w} / \mathrm{v}) \mathrm{NaCl}$ in nutrient broth and the incubation temperature was $27{ }^{\circ} \mathrm{C}$.

Colonies of the novel isolates on nutrient agar were round, convex, glossy, with entire margins and had a light grey or light yellow colour. Cells were Gram-positive, aerobic, exhibited a rod-coccus growth cycle, produced nonfluorescent pigment and were non-spore-forming and non-motile. The growth temperature range of strains
$\mathrm{LC}^{\mathrm{T}}$ and $\mathrm{LC}^{\mathrm{T}}$ was $5-40{ }^{\circ} \mathrm{C}$, however, strains $\mathrm{LC} 10^{\mathrm{T}}$ and $\mathrm{LC} 13^{\mathrm{T}}$ grew between 10 and $40{ }^{\circ} \mathrm{C}$. The optimal temperature for growth was $30{ }^{\circ} \mathrm{C}$ for all of the novel strains. The $\mathrm{pH}$ range for growth of strains $\mathrm{LC}^{\mathrm{T}}$ and $\mathrm{LC6}^{\mathrm{T}}$ was $\mathrm{pH} 6-$ 11 and was $6-10$ for strains $\mathrm{LC}_{10}{ }^{\mathrm{T}}$ and $\mathrm{LC}^{\mathrm{T}} 3^{\mathrm{T}}$. Strains $\mathrm{LC}^{\mathrm{T}}{ }^{2} \mathrm{LC}^{\mathrm{T}}$ and $\mathrm{LC}^{\mathrm{T}}{ }^{\mathrm{T}}$ could grow on nutrient broth medium with $7 \% \mathrm{NaCl}$. Strain $\mathrm{LC} 0^{\mathrm{T}}$ could grow on medium with $5 \% \mathrm{NaCl}$, but was unable to grow in the presence of $7 \% \mathrm{NaCl}$.

The 16S rRNA gene sequences of all members of the genus Arthrobacter and related genera obtained from DDBJ/ EMBL/GenBank were compared and a phylogenetic tree was constructed. The phylogenetic analysis included all recognized species of the genus Arthrobacter. The analysis based on 16S rRNA gene sequences indicated that all of the novel isolates belonged to the genus Arthrobacter. As can be seen in Fig. 1, the four novel isolates were divided into three clusters. At the 16S rRNA gene sequence level, strains $\mathrm{LC} 4^{\mathrm{T}}, \mathrm{LC}^{\mathrm{T}}, \mathrm{LC} 10^{\mathrm{T}}$ and $\mathrm{LC} 13^{\mathrm{T}}$ had sequence similarities of 97.0-97.4\% compared with A. chlorophenolicus JCM $12360^{\mathrm{T}}$ (GenBank accession no. AF102267), A. methylotrophus IAM $15313^{\mathrm{T}}$ (AF235090) and A. atrocyaneus IAM $12339^{\mathrm{T}}(\mathrm{X} 80746)$.

In order to determine the genotypic relatedness between the novel strains and recognized species of the genus Arthrobacter, DNA-DNA hybridization analyses were performed. The DNA-DNA relatedness value between strain $\mathrm{LC} 4^{\mathrm{T}}$ and $A$. chlorophenolicus was $32.1 \%$, between strain $\mathrm{LC6}^{\mathrm{T}}$ and $A$. methylotrophus, $14.1 \%$, between strain $\mathrm{LC} 10^{\mathrm{T}}$ and $A$. atrocyaneus, $11.2 \%$, between strain $\mathrm{LC} 10^{\mathrm{T}}$ and $\mathrm{LC}^{3} 3^{\mathrm{T}}, 25.3 \%$, and between strain $\mathrm{LC}^{\mathrm{T}}$ and $A$. atrocyaneus, $9.6 \%$. DNA-DNA relatedness below $70 \%$ is considered to be the threshold level for the separation of species (Wayne et al., 1987; Stackebrandt \& Goebel, 1994; Stackebrandt et al., 2002) and so these results show that strains $\mathrm{LC}^{\mathrm{T}}, \mathrm{LC}^{\mathrm{T}}, \mathrm{LC} 10^{\mathrm{T}}$ and $\mathrm{LC} 13^{\mathrm{T}}$ all represent novel genospecies.

The morphological and biochemical characteristics of the novel strains are shown in Table 1 . In the genus Arthrobacter, little or no acid is reported to be produced from glucose (Keddie et al., 1984), however, in this study, glucose could be oxidized by isolates $\mathrm{LC} 4^{\mathrm{T}}, \mathrm{LC}^{\mathrm{T}}$ and $\mathrm{LC} 10^{\mathrm{T}}$ and strain $\mathrm{LC} 13^{\mathrm{T}}$ showed weak activity. Isoprenoid menaquinone composition, fatty acid content and DNA $\mathrm{G}+\mathrm{C}$ content are shown in Table 2. All four novel strains had lysine as the diagnostic diamino acid of the cell-wall peptidoglycan. The major amino acids of the cell wall were lysine, alanine, serine and threonine. The major isoprenoid menaquinone for the novel isolates was MK- $9\left(\mathrm{H}_{2}\right)$. The major fatty acid was anteiso- $\mathrm{C}_{15: 0}(44.0-74.4 \%)$, but anteiso- $\mathrm{C}_{17: 0}(5.0-29.8 \%)$, iso- $\mathrm{C}_{15: 0}(3.0-35.5 \%)$ and iso$\mathrm{C}_{16: 0}(2.5-12.8 \%)$ were also present. The DNA G+C contents of strains $\mathrm{LC}^{\mathrm{T}}, \mathrm{LC}^{\mathrm{T}}, \mathrm{LC}^{\mathrm{T}} 0^{\mathrm{T}}$ and $\mathrm{LC}^{3} 3^{\mathrm{T}}$ were 70.8, 69.0, 71.8 and $70.8 \mathrm{~mol} \%$, respectively.

The differences in biochemical and chemotaxonomic characteristics indicated that the four new isolates $\mathrm{LC}^{\mathrm{T}}$, 


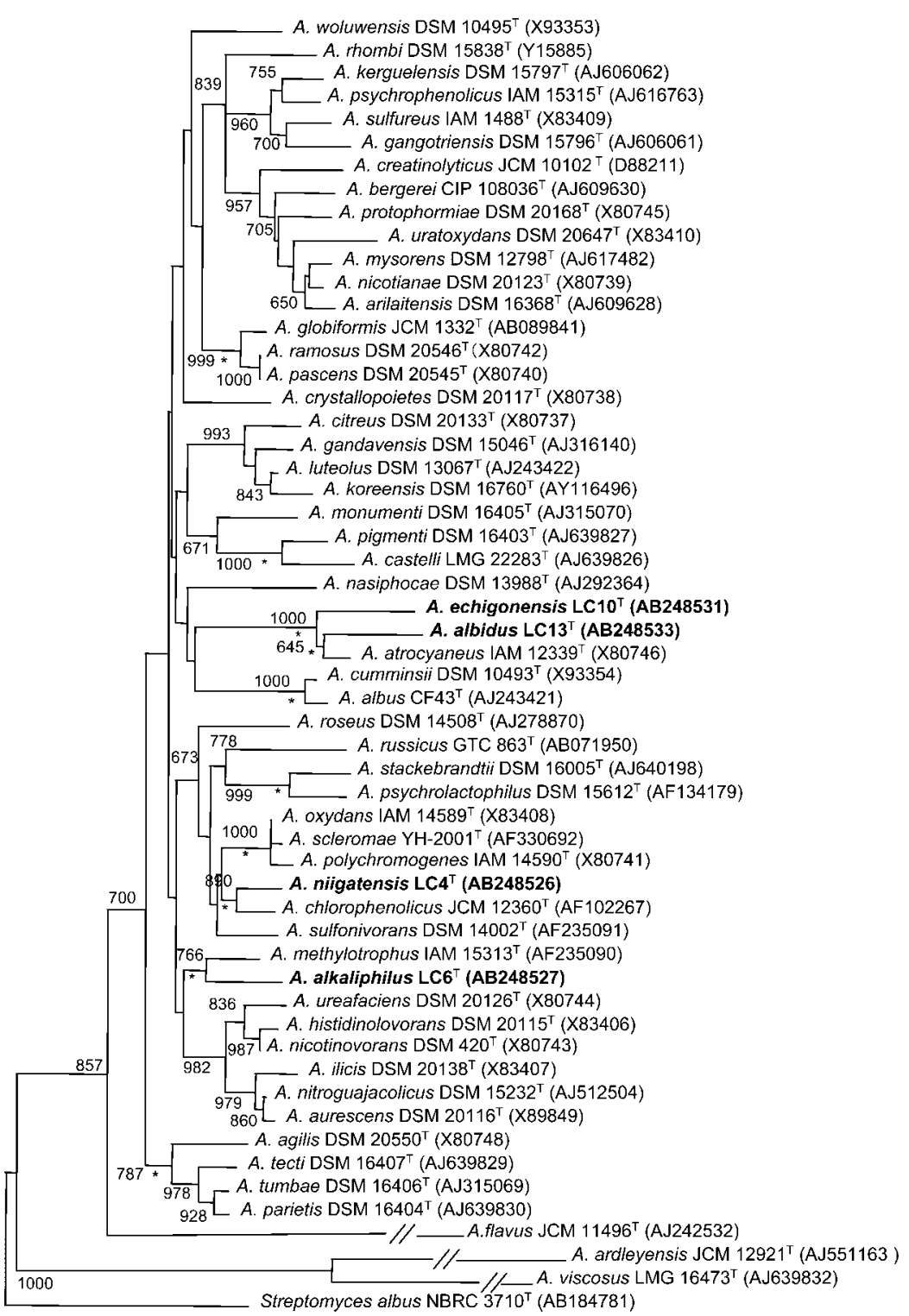

Fig. 1. Neighbour-joining tree based on almost complete 16S rRNA gene sequences, showing the phylogenetic position of strains $\mathrm{LC}^{\top}{ }^{\top}, \mathrm{LC}^{\top}, \mathrm{LC}_{10}{ }^{\top}$ and $\mathrm{LC}_{13}{ }^{\top}$ within the radiation of recognized Arthrobacter species. Asterisks indicate branches of the tree that were also found using the maximum-likelihood (Felsenstein, 1981) tree-making algorithms. Numbers at nodes indicate percentage levels of bootstrap support based on a neighbourjoining analysis of 1000 resampled datasets; only values over $60 \%$ are given. Bar, 0.01 substitutions per nucleotide position.
$\mathrm{LC}^{\mathrm{T}}, \mathrm{LC} 10^{\mathrm{T}}$ and $\mathrm{LC} 13^{\mathrm{T}}$ were distinct from the recognized species of the genus Arthrobacter and supported the proposal that the strains should be classified as four novel species of the genus Arthrobacter, for which the names Arthrobacter niigatensis sp. nov., Arthrobacter alkaliphilus sp. nov., Arthrobacter echigonensis sp. nov., and Arthrobacter albidus sp. nov., are proposed, respectively.

\section{Description of Arthrobacter niigatensis sp. nov.}

Arthrobacter niigatensis (ni.i.ga.ten'sis. N.L. masc. adj. niigatensis pertaining to the Niigata region, Japan).

Cells are non-motile and non-spore-forming. Grampositive, catalase-positive, oxidase-negative, shows a rod-coccus growth cycle and produces non-fluorescent pigment. Growth occurs on nutrient broth agar at 5$40{ }^{\circ} \mathrm{C}$, optimal temperature for growth is $30{ }^{\circ} \mathrm{C}$. Grows in the presence of 3-7\%(w/v) $\mathrm{NaCl}$. The $\mathrm{pH}$ range for growth is 6-11 and the optimum $\mathrm{pH}$ is 7.5. Colonies are round, convex, glossy, with entire margins and are light grey or light yellow. Using the API CORYNE system, a positive reaction is observed for reduction of nitrate, activities of pyrazinamidase, pyrrolidonyl arylamidase and urease, hydrolysis of gelatin and for the utilization of glucose, ribose, lactose and sucrose. A negative reaction is obtained for utilization of maltose and the utilization of mannitol, xylose and glycogen is weak. Using the API ZYM system, activity is detected for alkaline phosphatase, acid phosphatase, leucine arylamidase, trypsin, naphtholAS-BI-phosphohydrolase, esterase $\mathrm{C} 4$, esterase lipase $\mathrm{C} 8$, $\beta$-galactosidase, $\beta$-glucuronidase, $\alpha$-glucosidase, $\beta$-glucosidase and $\alpha$-mannosidase. No activity is detected for lipase C14, $\alpha$-galactosidase, $N$-acetyl- $\beta$-glucosaminidase, $\alpha$-chymotrypsin or $\alpha$-fucosidase. Activities of valine 
Table 1. Differential phenotypic characteristics of the novel strains

Taxa: 1, A. niigatensis sp. nov. LC4 ${ }^{\mathrm{T}} ; 2$, A. alkaliphilus sp. nov. $\mathrm{LC6}^{\mathrm{T}} ; 3$, A. echigonensis sp. nov. LC10 ${ }^{\mathrm{T}}$; , A. albidus sp. nov. LC13 ${ }^{\mathrm{T}}$; 5 , A. chlorophenolicus JCM $12360^{\mathrm{T}}$ (data from Westerberg et al., 2000); 6, A. methylotrophus IAM 15313 ${ }^{\mathrm{T}}$ (Borodina et al., 2002); 7, A. atrocyaneus IAM $12339^{\mathrm{T}}$ (Kuhn \& Starr, 1960). G, Grey; W, white; LY, light yellow; LG, light grey; PG, pearl grey; CY, creamy yellow; ND, no data; UK, contaminant on an agar plate; + , positive; $(+)$, weakly positive; - , negative.

\begin{tabular}{|c|c|c|c|c|c|c|c|}
\hline Characteristic & 1 & 2 & 3 & 4 & 5 & 6 & 7 \\
\hline Colony colour & LG/LY & LY & LG/LY & $\mathrm{W} / \mathrm{LY}$ & PG & $\mathrm{CY}$ & $\mathrm{G} / \mathrm{W}$ \\
\hline Optimum temperature & $25-37$ & $25-30$ & $25-37$ & $25-37$ & $20-30$ & 25 & $18-37$ \\
\hline Reduction of nitrate & + & - & - & - & - & $(+)$ & + \\
\hline Hydrolysis of gelatin & + & - & - & - & + & $(+)$ & $(+)$ \\
\hline \multicolumn{8}{|l|}{ Utilization of: } \\
\hline Maltose & - & + & $(+)$ & - & - & - & + \\
\hline Mannitol & $(+)$ & + & - & + & + & - & - \\
\hline Ribose & + & $(+)$ & + & + & + & + & - \\
\hline Sucrose & + & - & + & $(+)$ & + & + & - \\
\hline$\alpha$-Chymotrypsin & - & $(+)$ & - & - & + & + & - \\
\hline$\alpha$-Galactosidase & - & + & - & - & + & - & - \\
\hline$\beta$-Glucosidase & + & - & - & + & + & - & $(+)$ \\
\hline
\end{tabular}

arylamidase and cystine arylamidase are weak. The predominant fatty acids are anteiso- $\mathrm{C}_{15: 0}$, anteiso- $\mathrm{C}_{17: 0}$ and iso- $\mathrm{C}_{16: 0}$. The diamino acid of the cell-wall peptidoglycan is lysine and major components are lysine, serine, threonine and alanine. Menaquinones are $\mathrm{MK}$ 9( $\left.\mathrm{H}_{2}\right), \mathrm{MK}-8\left(\mathrm{H}_{2}\right)$ and $\mathrm{MK}-8\left(\mathrm{H}_{4}\right)$ (approx. 64, 17 and $15 \%$, respectively).

The type strain, strain $\mathrm{LC}^{\mathrm{T}}\left(=\mathrm{IAM} 15382^{\mathrm{T}}=\right.$ CCTCC AB $206012^{\mathrm{T}}$ ), was isolated from a filtration substrate made from volcanic rock from Niigata, Japan. The DNA G $+C$ content of the type strain is $70.8 \mathrm{~mol} \%$.

\section{Description of Arthrobacter alkaliphilus sp. nov.}

Arthrobacter alkaliphilus [al.ka.li'phi.lus. N.L. n. alkali (from the Arabic word al-qaliy) the ashes of saltwort; Gr. adj. philos loving; N.L. masc. adj. alkaliphilus loving alkaline environments].

Cells are non-motile and non-spore-forming. Grampositive, catalase-positive, oxidase-negative, shows a rod-coccus growth cycle and produces non-fluorescent pigment. Growth occurs on nutrient broth agar at 5$40{ }^{\circ} \mathrm{C}$, optimal temperature for growth is $30{ }^{\circ} \mathrm{C}$. Grows in the presence of $3-7 \%(\mathrm{w} / \mathrm{v}) \mathrm{NaCl}$. The $\mathrm{pH}$ range for growth is 6-11 and the optimum $\mathrm{pH}$ is 8.5 . Colonies are round, convex, glossy, with entire margins and are light yellow. Using the API CORYNE system, positive reactions are observed for activities of pyrazinamidase, pyrrolidonyl arylamidase and urease and for the utilization of glucose, ribose, maltose and mannitol. Negative reactions are obtained for nitrate reduction, for hydrolysis of gelatin and for utilization of glycogen, sucrose and xylose. Lactose gives a weak reaction. Using the API ZYM system, activity is detected for alkaline phosphatase, acid phosphatase, esterase lipase C8, leucine arylamidase, valine arylamidase, trypsin, naphthol-AS-BI-phosphohydrolase, $\alpha$-galactosidase, $\beta$-galactosidase, $\beta$-glucuronidase, $\alpha$-glucosidase and $\alpha$-mannosidase. No activity is detected for esterase $\mathrm{C} 4$, lipase $\mathrm{C} 14$, cystine arylamidase, $\beta$ glucosidase, $N$-acetyl- $\beta$-glucosaminidase or $\alpha$-fucosidase. The activity of $\alpha$-chymotrypsin is weak. Predominant fatty acids are anteiso- $C_{15: 0}$, anteiso- $C_{17: 0}$ and iso- $C_{16: 0}$. The diamino acid of the cell-wall peptidoglycan is lysine and the major components are lysine, serine, threonine and alanine. The menaquinone content is $\mathrm{MK}-9\left(\mathrm{H}_{2}\right)$, MK$10\left(\mathrm{H}_{2}\right)$ and MK-8 $\left(\mathrm{H}_{4}\right)$ (approx. 77, 17 and $3 \%$, respectively).

The type strain, strain $\mathrm{LC6}^{\mathrm{T}}\left(=\mathrm{IAM} 15383^{\mathrm{T}}=\right.$ CCTCC AB $206013^{\mathrm{T}}$ ), was isolated from a filtration substrate made from volcanic rock from Niigata, Japan. The DNA G $+C$ content of the type strain is $69.0 \mathrm{~mol} \%$.

\section{Description of Arthrobacter echigonensis sp. nov.}

Arthrobacter echigonensis (echi.go.nen'sis. N.L. masc. adj. echigonensis pertaining to the Echigo region, in Japan). 
Table 2. Chemotaxonomic characteristics of the novel species of the genus Arthrobacter

Taxa: 1, A. niigatensis sp. nov. $\mathrm{LC}^{\mathrm{T}}$; 2, A. alkaliphilus sp. nov. $\mathrm{LC}^{\mathrm{T}}$; 3, A. echigonensis sp. nov. LC10 ${ }^{\mathrm{T}}$; 4, A. albidus sp. nov. LC13 ${ }^{\mathrm{T}}$; 5, A. chlorophenolicus JCM $12360^{\mathrm{T}}$ (data from Westerberg et al., 2000); 6, A. methylotrophus IAM $15313^{\mathrm{T}}$ (Borodina et al., 2002); 7, A. atrocyaneus IAM $12339^{\mathrm{T}}$ (Koch et al., 1995). Menaquinone and fatty acid content data were obtained in this study. Lys, lysine; Ser, serine; Thr, threonine; Ala, alanine. Amino acids separated by hyphens indicate results from partial sequencing of peptiologlycan structure. Amino acids separated by commas indicate results of composition studies with no sequence study.

\begin{tabular}{|c|c|c|c|c|c|c|c|}
\hline Characteristic & 1 & 2 & 3 & 4 & 5 & 6 & 7 \\
\hline $\begin{array}{l}\text { Peptidoglycan amino acid } \\
\text { composition }\end{array}$ & Lys, Ser, Thr, Ala & Lys, Ser, Thr, Ala & Lys, Ser, Ala & Lys, Ser, Ala & Lys-Ser-Thr-Ala & Lys-Ala & Lys-Ser-Ala \\
\hline \multicolumn{8}{|l|}{ Menaquinones (\%): } \\
\hline MK-7 $\left(\mathrm{H}_{2}\right)$ & & & & & & 2 & \\
\hline MK-8 & & & & & 7.2 & & \\
\hline $\mathrm{MK}-8\left(\mathrm{H}_{2}\right)$ & 16.7 & 2.1 & 4.0 & 2.4 & & 6.0 & \\
\hline $\mathrm{MK}-8\left(\mathrm{H}_{4}\right)$ & 14.8 & 2.9 & & & & & \\
\hline MK-9 & & & & & 23.7 & 4.0 & \\
\hline MK-9 $\left(\mathrm{H}_{2}\right)$ & 64.2 & 77.0 & 82.6 & 82.9 & 60.9 & 79.0 & Major \\
\hline MK-10 $\left(\mathrm{H}_{2}\right)$ & & 17.0 & 5.7 & 14.0 & & 7.0 & \\
\hline MK-11 & & & & & 8.1 & & \\
\hline $\mathrm{MK}-11\left(\mathrm{H}_{2}\right)$ & & & & & & 1.0 & \\
\hline \multicolumn{8}{|l|}{ Fatty acids (\%): } \\
\hline iso- $\mathrm{C}_{14: 0}$ & 1.6 & 0.7 & 0.9 & 0.4 & 4.0 & 1.9 & 1.1 \\
\hline $\mathrm{C}_{14: 0}$ & 1.2 & 0.2 & 0.2 & 0.2 & 2.0 & 0.9 & 0.2 \\
\hline iso- $\mathrm{C}_{15: 0}$ & 8.4 & 4.5 & 14.7 & 14.5 & 7.0 & 7.1 & 29.0 \\
\hline anteiso- $\mathrm{C}_{15: 0}$ & 51.2 & 58.0 & 55.0 & 43.5 & 66.0 & 74.4 & 38.8 \\
\hline iso- $\mathrm{C}_{16: 0}$ & 12.8 & 7.1 & 5.8 & 5.3 & 10.0 & 5.7 & 9.5 \\
\hline $\mathrm{C}_{16: 0}$ & 5.6 & 1.1 & 0.8 & 1.1 & 3.0 & 1.6 & 0.9 \\
\hline Summed feature $3^{*}$ & 0.7 & & & & 1.0 & & \\
\hline iso- $\mathrm{C}_{17: 0}$ & 1.9 & 1.4 & 2.5 & 4.8 & & 0.3 & 4.7 \\
\hline anteiso- $\mathrm{C}_{17: 0}$ & 14.8 & 26.1 & 20.1 & 29.8 & 5.0 & 6.8 & 15.5 \\
\hline anteiso- $\mathrm{C}_{17: 1} \omega 9 c$ & 0.6 & & & & 1.0 & & \\
\hline DNA G + C content $(\mathrm{mol} \%)$ & 70.8 & 69.0 & 71.8 & 70.8 & 65.1 & 61.0 & $69.5-70.3$ \\
\hline
\end{tabular}

${ }^{\star}$ Summed feature $3, \mathrm{C}_{16: 1} \omega 7 c /$ iso- $\mathrm{C}_{15: 0}$ 2-OH.

Cells are non-motile and non-spore-forming. Grampositive, catalase-positive, oxidase-negative, shows a rod-coccus growth cycle and produces non-fluorescent pigment. Growth occurs on nutrient broth agar at 10$40{ }^{\circ} \mathrm{C}$, optimal temperature for growth is $30{ }^{\circ} \mathrm{C}$. Grows in presence of $3-5 \% \mathrm{NaCl}(\mathrm{w} / \mathrm{v})$, but no growth occurs in the presence of $7 \% \mathrm{NaCl}$. The $\mathrm{pH}$ range for growth is $6-$ 10 and the optimum $\mathrm{pH}$ is 7. Colonies are round, convex, glossy, with entire margins and are light grey or light yellow. Using the API CORYNE system, positive reactions are observed for activities of pyrazinamidase, pyrrolidonyl arylamidase and for the utilization of glucose, ribose and sucrose. Negative reactions are obtained for nitrate reduction, hydrolysis of gelatin, urease activity and for the utilization of xylose, mannitol, lactose and glycogen. Utilization of maltose is weak. By using the API ZYM system, activity is detected for alkaline phosphatase, acid phosphatase, esterase $\mathrm{C} 4$, esterase lipase $\mathrm{C} 8$, leucine arylamidase, valine arylamidase, cystine arylamidase, trypsin, naphthol-AS-BI-phosphohydrolase $\beta$-galactosidase, $\beta$-glucuronidase, $\alpha$-glucosidase and $\alpha$-mannosidase. No activity detected for lipase C14, $\alpha$-chymotrypsin, $\alpha$ - galactosidase, $\beta$-glucosidase, $N$-acetyl- $\beta$-glucosaminidase or $\alpha$-fucosidase. The predominant fatty acids are anteiso$\mathrm{C}_{15: 0}$, anteiso- $\mathrm{C}_{17: 0}$ and iso- $\mathrm{C}_{15: 0}$. The diamino acid of the cell-wall peptidoglycan is lysine and the major components are lysine, serine and alanine. The menaquinone content is MK-9 $\left(\mathrm{H}_{2}\right)$, MK-10 $\left(\mathrm{H}_{2}\right)$ and MK- $8\left(\mathrm{H}_{2}\right)$ (approx. 83, 6 and $4 \%$, respectively).

The type strain, strain $\mathrm{LC} 10^{\mathrm{T}}\left(=\mathrm{IAM} 15385^{\mathrm{T}}=\right.$ CCTCC AB $206017^{\mathrm{T}}$ ), was isolated from a filtration substrate made from volcanic rock from Niigata, Japan. The DNA G + C content of the type strain is $71.8 \mathrm{~mol} \%$.

\section{Description of Arthrobacter albidus sp. nov.}

Arthrobacter albidus (al'bi.dus. L. masc. adj. albidus whitish, referring to the colour of the colonies).

Cells are non-motile and non-spore-forming. Grampositive, catalase-positive, oxidase-negative, shows a rod-coccus growth cycle and produces non-fluorescent pigment. Growth occurs on nutrient broth agar at 10$40{ }^{\circ} \mathrm{C}$, optimal temperature for growth is $30{ }^{\circ} \mathrm{C}$. Grows in 
the presence of 3-7\% (w/v) NaCl, but no growth occurs in the presence of $7 \% \mathrm{NaCl}$. The $\mathrm{pH}$ range for growth is $6-10$, and the optimum $\mathrm{pH}$ is 7 . Colonies are round, convex, glossy, with entire margins and are white or light yellow. Using the API CORYNE system, positive reactions are observed for activities of pyrazinamidase, pyrrolidonyl arylamidase and urease and for the utilization of ribose and mannitol. Negative reactions are obtained for nitrate reduction, hydrolysis of gelatin and for the utilization of maltose, lactose and glycogen. Utilization of glucose, xylose and sucrose is weak. By using the API ZYM system, activity is detected for alkaline phosphatase, esterase lipase C8, leucine arylamidase, valine arylamidase, cystine arylamidase, trypsin, naphthol-AS-BI-phosphohydrolase, $\beta$-galactosidase, $\beta$-glucuronidase, $\alpha$-glucosidase, $\beta$-glucosidase and $\alpha$-mannosidase. No activity is detected for lipase C14, $\alpha$ chymotrypsin, $\alpha$-galactosidase, $N$-acetyl- $\beta$-glucosaminidase or $\alpha$-fucosidase. Esterase $\mathrm{C} 4$ and acid phosphatase activities are weak. The predominant fatty acids are anteiso- $\mathrm{C}_{15: 0}$, anteiso- $\mathrm{C}_{17: 0}$ and iso- $\mathrm{C}_{15: 0}$. The diagnostic diamino acid of the cell-wall peptidoglycan is lysine and the major components are lysine, serine and alanine. The menaquinone content is MK-9 $\left(\mathrm{H}_{2}\right)$, MK-10 $\left(\mathrm{H}_{2}\right)$ and MK- $8\left(\mathrm{H}_{4}\right)$ (approx. 83, 14 and 2\%, respectively).

The type strain, strain $\mathrm{LC}^{3} 3^{\mathrm{T}}\left(=\mathrm{IAM} 15386^{\mathrm{T}}=\mathrm{CCTCC}\right.$ $206018^{\mathrm{T}}$ ), was isolated from a filtration substrate made from volcanic rock from Niigata, Japan. The DNA G + C content of the type strain is $70.8 \mathrm{~mol} \%$,

\section{References}

Borodina, E., Kelly, D. P., Schumann, P., Rainey, F. A., Ward-Rainey, N. L. \& Wood, A. P. (2002). Enzymes of dimethylsulfone metabolism and the phylogenetic characterization of the facultative methylotrophs Arthrobacter sulfonivorans sp. nov., Arthrobacter methylotrophus sp. nov., and Hyphomicrobium sulfonivorans sp. nov. Arch Microbiol 177, 173-183.

Carter, J. P., Hsiao, Y. H., Spiro, S. \& Richardson, D. J. (1995). Soil and sediment bacteria capable of aerobic nitrate respiration. Appl Environ Microbiol 61, 2852-2858.

Conn, H. J. \& Dimmick, I. (1947). Soil bacteria similar in morphology to Mycobacterium and Corynebacterium. J Bacteriol 54, 291-303.

Ding, L. \& Yokota, A. (2002). Phylogenetic analysis of the genus Aquaspirillum based on 16S rRNA gene sequences. FEMS Microbiol Lett 212, 165-169.

Ding, L. \& Yokota, A. (2004). Proposals of Curvibacter gracilis gen. nov., sp. nov. and Herbaspirillum putei sp. nov. for bacterial strains isolated from well water and reclassification of [Pseudomonas] huttiensis, [Pseudomonas] lanceolata, [Aquaspirillum] delicatum and [Aquaspirillum] autotrophicum as Herbaspirillum huttiense comb. nov., Curvibacter lanceolatus comb. nov., Curvibacter delicatus comb. nov. and Herbaspirillum autotrophicum comb. nov. Int J Syst Evol Microbiol 54, 2223-2230.

Duarte, G. F., Rosado, A. S., Seldin, L., de Araujo, W. \& van Elsas, J. D. (2001). Analysis of bacterial community structure in sulfurous-oilcontaining soils and detection of species carrying dibenzothiophene desulfurization (dsz) genes. Appl Environ Microbiol 67, 1052-1062.

Ezaki, T., Hashimoto, Y. \& Yabuuchi, E. (1989). Fluorometric deoxyribonucleic acid-deoxyribonucleic acid hybridization in microdilution wells as an alternative to membrane filter hybridization in which radioisotopes are used to determine genetic relatedness among bacterial strains. Int J Syst Bacteriol 39, 224-229.

Felsenstein, J. (1981). Evolutionary trees from DNA sequences: a maximum likelihood approach. J Mol Evol 17, 368-376.

Felsenstein, J. (1985). Confidence limits on phylogenies: an approach using the bootstrap. Evolution 39, 783-791.

Fukatsu, H., Goda, M., Hashimoto, Y., Higashibata, H. \& Kobayashi, M. (2005). Optimum culture conditions for the production of $\mathrm{N}$ substituted formamide deformylase by Arthrobacter pascens F164. Biosci Biotechnol Biochem 69, 228-230.

Harper, J. J. \& Davis, G. H. G. (1979). Two-dimensional thin-layer chromatography for amino acid analysis of bacterial cell walls. Int $J$ Syst Bacteriol 29, 56-58.

Heyrman, J., Verbeeren, J., Schumann, P., Swings, J. \& Paul, D. V. (2005). Six novel Arthrobacter species isolated from deteriorated mural paintings. Int J Syst Evol Microbiol 55, 1457-1464.

Jussila, M. M., Jurgens, G., Lindstrom, K. \& Suominen, L. (2006). Genetic diversity of culturable bacteria in oil-contaminated rhizosphere of Galega orientalis. Environ Pollut 139, 244-257.

Keddie, R. M., Collins, M. D. \& Jones, D. (1984). Genus Arthrobacter Conn and Dimmick 1974, 300 AL. In Bergey's Manual of Systematic Bacteriology, vol. 1, pp. 1288-1301. Edited by N. R. Klieg \& J. G. Holt. Baltimore, MD: Williams \& Wilkins.

Kimura, M. (1980). A simple method for estimating evolutionary rates of base substitutions through comparative studies of nucleotide sequences. J Mol Evol 16, 111-120.

Koch, C., Schmann, P. \& Stackebrandt, E. (1995). Reclassification of Micrococcus agilis (Ali-Cohen 1889) to the genus Arthrobacter as Arthrobacter agilis comb. nov. and emendation of the genus Arthrobacter. Int J Syst Bacteriol 45, 837-839.

Kuhn, D. A. \& Starr, M. P. (1960). Arthrobacter atrocyaneus, n. sp., and its blue pigment. Arch Mikrobiol 36, 175-181.

Li, Y., Kawamura, Y., Fujiwara, N., Naka, T., Liu, H., Huang, X., Kobayashi, K. \& Ezaki, T. (2004). Rothia aeria sp. nov., Rhodococcus baikonurensis sp. nov. and Arthrobacter russicus sp. nov., isolated from air in the Russian space laboratory Mir. Int J Syst Evol Microbiol 54, 827-835.

Margesin, R., Schumann, P., Spröer, C. \& Gounot, A. M. (2004). Arthrobacter psychrophenolicus sp. nov., isolated from an alpine ice cave. Int J Syst Evol Microbiol 54, 2067-2072.

Marks, T. S., Smith, A. R. \& Quirk, A. V. (1984). Degradation of 4chlorobenzoic acid by Arthrobacter sp. Appl Environ Microbiol 48, 1020-1025.

Mesbah, M., Premachandran, U. \& Whitman, W. B. (1989). Precise measurement of the $\mathrm{G}+\mathrm{C}$ content of deoxyribonucleic acid by highperformance liquid chromatography. Int J Syst Bacteriol 39, 159-167.

Rzechowska, E. (1976). Studies on the biodegradation of nonionic surfactants applied in the polyester fiber industry. I. Activated sludge bacteria degrading the surfactants. Acta Microbiol Pol 25, 211-217.

Saitou, N. \& Nei, M. (1987). The neighbor-joining method, a new method for reconstructing phylogenetic trees. Mol Biol Evol 4, 406425.

Sambrook, J., Fritsch, E. F. \& Maniatis, T. (1989). Molecular Cloning: a Laboratory Manual, 2nd edn. Cold Spring Harbor, NY: Cold Spring Harbor Laboratory.

Sasser, M. (1990). Identification of bacteria by gas chromatography of cellular fatty acids. MIDI Technical Note, 101. Newark, DE: MIDI Inc.

Schleifer, K. H. \& Kandler, O. (1972). Peptidoglycan types of bacterial cell walls and their taxonomic implications. Bacteriol Rev 36, 407-477. 
Sguros, P. L. (1955). Microbial transformations of the tobacco alkaloids. I. Cultural and morphological characteristics of a nicotinophile. J Bacteriol 69, 28-37.

Singer, A. C., Gilbert, E. S., Luepromchai, E. \& Crowley, D. E. (2000). Bioremediation of polychlorinated biphenyl-contaminated soil using carvone and surfactant-grown bacteria. Appl Microbiol Biotechnol 54, 838-843.

Skerman, V. B. D., McGowan, V. \& Sneath, P. H. A. (editors) (1980). Approved lists of bacterial names. Int J Syst Bacteriol 30, 225-420.

Stackebrandt, E. \& Goebel, B. M. (1994). Taxonomic note: a place for DNA-DNA reassociation and $16 \mathrm{~S}$ rRNA sequence analysis in the present species definition in bacteriology. Int J Syst Bacteriol 44, 846849.

Stackebrandt, E., Fowler, V. J., Fiedler, F. \& Seiler, H. (1983). Taxonomic studies on Arthrobacter nicotianae and related taxa: description of Arthrobacter uratoxydans sp. nov. and Arthrobacter sulfureus sp. nov. and reclassification of Brevibacterium protophormiae as Arthrobacter protophormiae comb. nov. Syst Appl Microbiol 4, 470-486.

Stackebrandt, E., Frederiksen, W., Garrity, G. M., Grimont, P. A., Kämpfer, P., Maiden, M. C., Nesme, X., Rosselló-Mora, R., Swings, J. \& other authors (2002). Report of the ad hoc committee for the re-evaluation of the species definition in bacteriology. Int J Syst Evol Microbiol 52, 1043-1047.

Takeuchi, M. \& Yokota, A. (1991). Reclassification of strains of Flavobacterium-Cytophaga group in IFO culture collection. Inst Ferment Osaka Res Commun 15, 83-96.

Thompson, J. D., Higgins, D. G. \& Gibson, T. J. (1994). ClustaL W: improving the sensitivity of progressive multiple sequence alignment through sequence weighting, position-specific gap penalties and weight matrix choice. Nucleic Acids Res 22, 4673-4680.

Wayne, L. G., Brenner, D. J., Colwell, R. R., Grimont, P. A. D., Kandler, O., Krichevsky, M. I., Moore, L. H., Moore, W. E. C., Murray, R. G. E. \& other authors (1987). International Committee on Systematic Bacteriology. Report of the ad hoc committee on reconciliation of approaches to bacterial systematics. Int J Syst Bacteriol 37, 463-464.

Westerberg, K., Elvang, A. M., Stackebrandt, E. \& Jansson, J. K. (2000). Arthrobacter chlorophenolicus sp. nov., a new species capable of degrading high concentrations of 4-chlorophenol. Int J Syst Evol Microbiol 50, 2083-2092.

Willems, A., Doignon, B. F., Goris, J., Coopman, R., Lajudie, P., Vos, D. P. \& Gillis, M. (2001). DNA-DNA hybridization study of Bradyrhizobium strains. Int J Syst Evol Microbiol 51, 1315-1322. 